\title{
ARTICLES
}

\section{DIMENSIONS OF LENIENCY POLICIES IN BRICS: A COMPARATIVE ANALYSIS OF INDIA, SOUTH AFRICA, BRAZIL AND RUSSIA}

\author{
DEEPANKAR SHARMA, \\ National Law University Jodhpur (Jodhpur, India)
}

DOI: $10.21684 / 2412-2343-2016-3-2-6-20$

A cartel is a group of similar, independent companies which join together to fix prices, limit production or share markets or customers among themselves. The most significant feature of this anticompetitive activity is its restriction of competition between the parties involved in the arrangement. The objective of a cartel is to raise prices above competitive levels, which can result in injury to consumers and to the economy. This is why cartels are considered not only harmful for the economy as a whole but also, as a catalysing factor, destructive for the idealized approach of maintaining a level playing field in the market. Thus various jurisdictions, or rather almost all competition regimes, declare cartels an illegal activity subject to severe fines and penalties. But it is well known that the enforcement mechanisms of laws against cartels differ from country to country, and yet the striking similarity is that almost all competition authorities face the same uphill task of detecting and busting cartels in a manner that leads to efficient and desired prosecution.

This paper focuses on an analysis of the newly introduced leniency regulations in India and the parameters of their effectiveness through a comparative analytical study of BRICS leniency regulations, specifically the experiences shared by South Africa, Brazil and Russia in the application of leniency tools and a marker system. The paper further considers the weaknesses of the existing leniency regulations in India and in BRICS and concludes by offering a future path for possible improvements in the form of certain recommendations.

Keywords: cartel; India; South Africa; Brazil; Russia; leniency policy; marker system.

Recommended citation: Deepankar Sharma, Dimensions of Leniency Policies in Brics: a Comparative Analysis of India, South Africa, Brazil and Russia, 3(2) BRICS Law Journal 6-20 (2016). 


\section{Table of contents}

\section{Introduction}

\subsection{Cartels}

2. Important Prerequisites for Effective Leniency Policy

3. Theory of Leniency Policy: Common Elements

4. Leniency Programmes and Detection of Cartels

4.1. Benefits of Leniency Programmes

5. Cartel Penalties in India: Optimal or Non-Optimal

6. Leniency Programme in India (Lesser Penalty Regulations, 2009)

6.1. Nature and Scope

7. Practical Aspects of Administering Leniency: Marker System

\subsection{Extensions to the Marker Period}

8. Role of Leniency in Busting Multiple Cartels: a Cue from the US Regime 8.1. Leniency Programmes in Developing Countries

9. BRICS Countries and Leniency: Glimpses from South Africa, Brazil \& Russia

\subsection{South Africa}

\subsection{Brazil}

\subsection{Russia}

10. Competition Policy: Options for Enforcement Agencies in Context of Leniency Policy

11. Concluding Remarks

\section{Introduction}

Hard-core cartels' are one of the most complex and serious forms of anticompetitive activity in the modern world. Cartelists take advantage of, and obtain undue benefit at the expense of, their counterparts and other parties. Consequently, almost all countries look at the ways and means available to stop the anticompetitive activity they engage in. Prosecuting and deterring cartels is the crux of their anti-cartel drive. But cartels have a particular feature in that that are very secretive - so much so that their identification and prosecution is difficult. But not impossible, for their identity can and does become known to enforcement agencies from within the cartels themselves, that is to say, through insider information leaked to the agencies. And this leads to one of the most efficient tools for detection of cartels, namely,

\footnotetext{
'Hard-core' cartel conduct has been defined by the Organisation for Economic Co-operation and Development (OECD) as, "[A]n anti-competitive agreement, anti-competitive concerted practice, or anti-competitive arrangement by competitors to fix prices, make rigged bids (collusive tenders), establish output restrictions or quotas, or share or divide markets by allocating customers, suppliers, territories, or lines of commerce" (OECD 1998).
} 
leniency programmes. These programmes incentivize the members of a cartel to leak information along with evidence in return for the certain substantial benefit of immunity from prosecution.

Leniency is a generic term to describe a system of partial or total exoneration from the penalties that would otherwise be applicable to a cartel participant in return for reporting its cartel membership and supplying information or evidence related to the cartel to the competition agency providing leniency. The terms 'leniency', 'immunity' and 'amnesty' are used in many jurisdictions, but the definitions of these terms vary between jurisdictions. For example, under the United States leniency program, 'corporate amnesty' and'corporate leniency' are used interchangeably to mean complete immunity from criminal conviction and fines. Other jurisdictions use'leniency' to refer to any reduction in fines up to 100 per cent. $^{2}$

A leniency programme is a system, publicly announced, of "partial or total exoneration from the penalties that would otherwise be applicable to a cartel member who reports its cartel membership to a competition [law] enforcement agency." The term 'leniency policy' is used to describe the written collection of principles and conditions adopted by a competition agency that governs the leniency process. A 'leniency programme' also includes internal agency processes, for example, how the competition agency implements its leniency policy, including processes for conferring and/or refusing leniency or lenient treatment.

\subsection{Cartels}

The most significant arrangement to adversely affect competition and achieve monopolistic influence is the formation of a cartel. It not only distorts the market share pattern but also restricts freedom of trade by obstructing the promotion of suitable and best quality products and reducing the accessibility to the market for the customer. ${ }^{3}$ The parties to this anticompetitive arrangement obtain an undue advantage to regulate prices or output and thereby interfere with the existing market pattern.

2 International Competition Network, Anti-Cartel Enforcement Manual, Chapter 2: Drafting and Implementing an Effective Leniency Policy, Section 2.1, April 2014, available at $<\mathrm{http}: / / \mathrm{www}$. internationalcompetitionnetwork.org/uploads/library/doc1005.pdf> (accessed June 15, 2016).

3 S. Chaitanya Shashank, Comparative Analysis of Cartel Laws of India and European Union, Academike: Lawctopus Law Journal, available at <http://www.lawctopus.com/academike/cartel-laws-of-indiaand-european-union/> (accessed June 3, 2016). 


\section{Important Prerequisites for Effective Leniency Policy}

If a cartelist seeks an application for leniency, he first has to confess to cartel activity, cease his participation and subsequently cooperate with the authorities in providing adequate evidence that could lead to substantial prosecution. The anticartel enforcement agencies, on their part, show a commitment to a uniform and lenient pattern of punishment so as to induce more potential leniency seekers. Significantly, the unique part of this exercise is that leniency is available only to the first applicant and not to others, for if lenient treatment is given to more than one player, leniency policy might lose its attraction. Hence, to induce a cartel player to confess, the following conditions have to be fulfilled in a straightforward manner:

1) Anti-cartel enforcement has to be active in spreading a belief among cartel players that there is a high risk of detection if timely application for leniency is not made;

2) Penalties to be imposed on non-leniency application seekers should be harsh and predictably deterrent. This penalty should also show clear distinction between the self-confessing player and the non-leniency seeker where the latter receives much higher punishment;

3) The leniency programme should include the element of transparency and predictability where the applicant knows the treatment he can expect in advance;

4) To bust international cartels, the leniency programme should include confidentiality of information where the applicant and his information are not revealed to other cartelists.

Leniency programmes are designed in such a way that they induce cartel members to voluntary confession and harmonious cooperation with enforcement agencies. Programmes should develop a sense of mutual trust and benefit between potential applicants and enforcement agencies. They should reward one or only a few players with reduced penalties or immunity (in comparison to non-leniency seekers or still active cartel players). In other words, programmes aim at stimulating a rush to become the first whistle-blower rather than remain an active cartel player under threat of heavy penalty. ${ }^{4}$

\section{Theory of Leniency Policy: Common Elements}

Cartels can break down for many reasons and external shock or entry can be among them. According to the cartel literature, it has been observed that bargaining is a bigger reason for breakdown than cheating. The most successful cartels develop

4 UNCTAD Note on The use of leniency programmes as a tool for the enforcement of competition law against hardcore cartels in developing countries, TD/RBP/CONF.7/4, published on 26 August 2010, available at <http://unctad.org/en/Docs/tdrbpconf7d4_en.pdf> (accessed June 10, 2016). 
mechanisms to accommodate external changes, thereby reducing the need to renegotiate. ${ }^{5}$ Effective enforcement of antitrust laws also adds to the list of reasons for cartel breakdowns. However, despite tougher sanctions in the past decade, their continued discovery indicates that cartels remain under-deterred. ${ }^{6}$ This occurs because in one location cartels may not be prosecuted to the level that they cause harm to the economy and in another location cartels in foreign markets, even if they cause harm there, may not be prosecuted by the other jurisdiction on legal grounds.

Leniency programmes aim to tackle cartels. Since cartels are illegal and if detected may lead to hefty fines or criminal sanctions, they are kept secret by the involved players. Members of cartels try to keep hidden or destroy evidence that might lead to their exposure. The leniency seeker of a cartel most often not only describes the modus operandi of the cartel, but also provides substantial information about the involvement of other players.

The most striking feature of any leniency policy is the expected increase in the amount of punishment after the detection of the cartel. There can be the instance where a few cartelists have received lesser penalties, but the fact that more cartels are brought under the scrutiny of the investigation depicts the success of the leniency policy. This not only compensates for the loss incurred owing to reduced penalties for some, but also leads to the situation of demoralizing potential cartelists from future participation in cartel activity.

But theory also leads to a point of distinction between leniency and settlement. Leniency, as it is used, is the pre-investigation tool where the actual trial has not yet begun and the involved player is induced to leak evidence that might be presented in court. In contrast, settlement is an agreement where the competition agency and the player resolve on certain issues at the time of adjudication itself. Settlement, by and large, aims at reducing the costs and latches in the adjudication process.

\section{Leniency Programmes and Detection of Cartels}

In the words of the International Competition Network Working Group recommendation concerning effective action against hard-core cartels, of 1998, " $[\mathrm{H}]$ ard core cartels are the most egregious violations of competition law."7

\footnotetext{
5 UNCTAD Note on The use of leniency programmes as a tool for the enforcement of competition law against hardcore cartels in developing countries, TD/RBP/CONF.7/4, published on 26 August 2010, available at <http://unctad.org/en/Docs/tdrbpconf7d4_en.pdf> (accessed June 10, 2016).

6 Connor and Lande, 2008, Cartel detection is not fading away, Pg 2216, Cited in UNCTAD Report TD/ RBP/CONF.7/4, published on 26 August 2010.

7 Defining Hard Core Cartel Conduct: Effective Institutions, Effective Penalties: Report by the ICN Working Group on Cartels; available at < http://www.internationalcompetitionnetwork.org/uploads/library/ doc346.pdf> (accessed 7 June, 2016).
} 
It is for the detection of 'Hard Core Cartels' (HCC) that a leniency programme is used. A leniency programme attempts to regulate and detect cartels and offers an exemption or reduction in penalties, which could be substantial, in exchange for cooperation from the informant.

\subsection{Benefits of Leniency Programmes}

Detection of cartels through leniency programmes bolsters cartel deterrence by increasing the expected probability that sanctions will be applied; the leniency programme has a destabilizing effect on potential cartels, as only the first leniency applicant will be granted leniency; these programmes facilitate the investigation and prosecution of cartel participants as the leniency applicants provide evidence, which otherwise might not be available; and leniency programmes induce cooperating companies to provide useful information on the existence of other cartels, which can be investigated subsequently. ${ }^{8}$ Thus, if we examine the role played by leniency policies, we can deduce the following benefits:

1. Improved collection of intelligence and evidence. It has been observed that there are three methods of obtaining evidence: 1) direct force, 2) threats against company staff of sanctions in case of non-cooperation and 3) offers of leniency. The third method has advantages over the other two in several respects. Firstly, leniency can be used to obtain all sorts of information and is not confined only to existing documents and records, as is the case in the first method. Secondly, leniency saves an equal amount of time and resources as the second method but does not suffer from the problem of reliability as is the case in the second method, because the applicants know that there is no reward for providing wrong information - on the contrary, this would invite penalties and a disqualification from being considered for leniency.

2. Increased difficulty of maintaining cartels. Maintaining a cartel is an enormous task; all the participants have to coordinate their behaviour on consistent and collusive strategies allowing the participants to increase their profits. A leniency programme can be very effective in situations like these: it increases the payoff from cheating for the deviator, thereby making it difficult for the cartel to sustain itself. The higher the incentive offered is, the higher will be the chances of cheating.

3. Lower cost of adjudication. Leniency is a cost-saving method that does not involve the time consumed in court proceedings, as the delinquent company would prefer not to be held liable and to receive an incentive in the form of a reduction in penalties or no penalty imposed at all. ${ }^{9}$

8 Gregory J. Werden, Scott D. Hammond, Belinda A. Barnett, Deterrence and detection of cartels: using all the tools and sanctions, 56(2)The Antitrust Bulletin (2011).

9 Wouter P.J. Wils, Leniency in Antitrust Enforcement: Theory and Practice, available at <http://papers. ssrn.com/sol3/cf_dev/AbsByAuth.cfm?per_id=456087> (accessed June 7, 2016). 


\section{Cartel Penalties in India: Optimal or Non-Optimal}

The Competition Commission of India (CCl) is authorized by law to act on the information it receives, or it may even take action suo mottu on the basis of information it has against cartel activities. Upon reaching the conclusion of the existence of a cartel, the $\mathrm{CCl}$, under Section 27 of the Competition Act 2002 (Competition Act or the Act), may impose on a cartel participant "a penalty of up to three times of its profit for each year of the continuance of such agreement or ten percent of its turnover for each year of the continuance of such agreement, whichever is higher." Further, individuals involved in the relevant conduct of the company also face punishment.

Concerns have been raised time and again regarding the effectiveness and the authority of Indian laws in dealing with cartel activity. It has been noted that jurisdictions which have stricter cartel penalties as compared to India have been quite successful in detection of cartels.

Leniency provisions, considered to be perhaps the most efficient tool to detect cartels, may affect the anti-cartel enforcement mechanism in any jurisdiction to a great extent. Australia's example of imposing criminal sanctions for cartels has led to an increase in leniency applications. In contrast, Indian law has failed to attract leniency applications ever since its inception. Therefore, India has arrived at the point where there is an urgent need to revisit its laws for addressing this issue.

\section{Leniency Programme in India (Lesser Penalty Regulations 2009)}

In India, the Competition Act 2002 incorporates the leniency principle under Section 46. This section of the Act empowers the $\mathrm{CCl}$ to impose a lesser penalty in respect of violation of Section 3 with reference to cartel cases in accordance with the provisions of Section 46.

However, it is important to note that the power to impose a lesser penalty is not in the nature of a right of the party seeking leniency. In other words, the $\mathrm{CCl}$ has discretion in matters relating to imposing a lesser penalty, and hence parties cannot claim leniency as a matter of right. Discretion is not without guidance, as the Competition Act 2002 in its wisdom lays down the conditions for obtaining leniency, which in turn creates an atmosphere of transparency.

Under the Competition Act 2002, the overall responsibility for inquiring into contravention of the provisions relating to anticompetitive agreements, including cartels, is conferred on the $\mathrm{CCl} .^{10}$

\footnotetext{
10 Section 19 of the Competition Act 2002.
} 


\subsection{Nature and Scope}

Under Section 46 of the Act, more than one cartel member can avail itself of the benefit of a lesser penalty. ${ }^{11}$ Hence, the lesser penalty provision may be applied by the $\mathrm{CCl}$ by way of full waiver of penalty (immunity) or less than full penalty (leniency). In other words, the concepts of immunity and leniency may be incorporated under the regulation for a lesser penalty. ${ }^{12}$

\subsection{Applicability of Leniency Programmes}

Also under Section 46, the following cartel members are eligible for invoking lesser penalty provisions, namely: any producer, seller, distributor, trader or service provider.

\subsection{Procedure for Receiving Leniency Applications}

Applications for a lesser penalty under Section 46 of the Competition Act 2002 may be made orally or in writing.

\subsection{Procedure for Maintaining Confidentiality in Leniency Applications}

Section 57 of the Act stipulates that information relating to an enterprise obtained by or on behalf of the $\mathrm{CCl}$ or the Competition Appellate Tribunal for the purposes of the Act will not be disclosed otherwise than in compliance with or for the purposes of the Act or any other law at the time in force. Further, any such disclosure will be with the previous permission in writing of the enterprise.

\subsection{Appeals on Rejection of Leniency Application}

Appeal against any direction, decision or order of the Competition Commission of India in relation to a lesser penalty provision will lie with the Competition Appellate Tribunal. ${ }^{13}$

\subsection{Revocation of Leniency}

A lesser penalty granted under Section 46 is subject to certain conditions. A conditional lesser penalty may be revoked if the $\mathrm{CCl}$ is satisfied that any cartel member in the course of proceedings had not complied with the conditions on which the lesser penalty was imposed and there upon will impose a penalty to which the member was liable had a lesser penalty not been imposed..$^{14}$

11 Provided further that a lesser penalty will be imposed by the Commission only in respect of a producer, seller, distributor, trader or service provider included in the cartel, who has made the full, true and vital disclosures under this section.

12 Competition authorities the world over provide leniency in terms of $100 \%$ immunity from fines or reduction in fines up to a certain percentage on the basis of various factors such as amount of knowledge or information available with competition authorities to initiate an investigation; time of making leniency application, i.e. before or after investigation; first to make application; etc.

13 Section 53A of the Competition Act 2002.

14 Fourth proviso to Section 46, Competition Act 2002. 


\subsection{Information Constituting Evidence}

The information that makes a party eligible for leniency application is provided in a Schedule annexed to the Act. This includes:

- Relevant names and addresses.

- A detailed description of the alleged cartel arrangement.

- The goods or services involved.

- The geographic market covered.

- Commencement date and duration of the cartel.

- The estimated volume of business affected by the alleged cartel.

- Names and details of all individuals who, in the knowledge of the applicant, are or have been involved in the cartel, including on behalf of the applicant.

- Details of other competition authorities, forums or courts, if any, approached or intended to be approached in relation to the alleged cartel.

- A descriptive list of evidence provided in support of the application.

- Any other material information as may be directed by the CCI.

\section{Practical Aspects of Administering Leniency: Marker System}

A 'marker' system in the context of leniency policy relates to the means for leniency applicants to reserve their place for a defined period of time pending further investigations and to attempt to cement their place as the first applicant for leniency whenever the competition agencies determine this question. Markers are granted by the agencies with receipt of incomplete information at the initial phase or any evidence as provided by the leniency applicant.

The leniency applicant's position under the marker system is reserved for a fixed duration on the condition that the applicant will provide further information or corroborating evidence to the agency within the agreed time frame. Thus, the 'marker' provides certainty and clarity for potential leniency applicants. The marker system acts as a catalyst or additional inducement for reaching out to the competition agency with substantial information or evidence at the earliest available opportunity. If further investigations by the agency on the basis of supplied information by the prospective applicant fail to disclose a breach of the law, the marker may be withdrawn, revoked or allowed to lapse.

Some competition agencies extend the marker beyond the first informant under the leniency setup. These agencies provide for amassing information and queuing up the leniency seekers, as they consider such queuing helpful in ensuring sustained cooperation from the applicant that holds the first place in the marker system and in compelling them to provide further information from other parties. ${ }^{15}$

15 International Competition Network, Anti-Cartel Enforcement Manual, Chapter 2: Drafting and Implementing an Effective Leniency Policy, April 2014, available at <http://www.internationalcompetitionnetwork.org/ uploads/library/doc1005.pdf> (accessed June 15, 2016). 


\subsection{Extensions to the Marker Period}

Certain jurisdictions grant markers for specific periods (28 days, for example) to encourage a company to further strengthen its leniency application. But this period may be extended at the discretion vested in the competition agencies on the likelihood that an extension will be a key factor in bringing to light additional information on the existence of a cartel. This obviously should be backed by the bona fide intention of the applicant along with the steps taken by him to retrieve the crucial information or evidence that may establish the existence of a cartel.

This may occur for a number of good reasons, for example if certain aspects of the investigation are not under the effective control of the applicant or evidence is outside the jurisdiction or the modus operandi is more complex than initially perceived. Having said that, it may also be noted that inflexible time frames for a marker may reduce the advantages of early reporting. Furthermore, for the prospective leniency seeker, it may even reduce the attraction of providing information early.

\section{Role of Leniency in Busting Multiple Cartels: a Cue from the US Regime}

Leniency programmes have been created to increase the incentivizing process of cartel reporting. This is based on the fact that a given cartel player may not be involved in one market only, but rather may have a presence in other markets as well, and thus information provided by any one given player can be useful for testing cartel activity in other markets also. Provisions in antitrust law mentioned by the US Department of Justice may further increase the chances of busting cartels in different domains:

a) 'Amnesty Plus' encourages a cartelist under the agency's scrutiny in the context of one particular cartel to apply for simultaneous leniency in the context of another cartel, and become the recipient of a penalty reduction not only for the newly disclosed cartel but also for the cartel already under examination by the agency;

b) 'Penalty Plus' increases the prospective penalty if the cartelist had the opportunity of taking advantage of 'Amnesty Plus' but never did so and the cartel was busted later and successfully prosecuted;

c) The 'Omnibus Question' is asked of persons who are witnesses under oath in a cartel investigation. They are asked whether they know about cartel activity in any other market than the one at hand. Being subject to perjury penalties, they have a greater willingness to disclose information about other cartels.

These provisions in the form of the carrot and stick approach have their successful impact. The leading example in is the vitamins cartels in twelve different markets that were discovered in a chain of investigation disclosures one after the other. Another example is the busting of the initially perceived lysine cartel that further 
led to the citric cartel, and so on. Other jurisdictions may want to take a leaf out of the US agency's book and develop their laws accordingly.

\subsection{Leniency Programmes in Developing Countries}

Few countries, especially those with developing or emerging market economies, have taken the steps to fight cartel activity through the use of leniency programmes, but the fight against cartels should be taken up by virtually all countries. We have to note that while trying to extend the reach of leniency policies to a majority of countries it is pertinent to keep in mind that the model useful for developed countries may not be effective as the model for developing countries, simply because commercial perspectives cannot have a one-size-fits-all formula. For this reason we have undertaken an analysis of emerging market economies and their experiences with leniency programmes. One such category of emerging or like-minded markets is BRICS, where we have already mentioned the situation in respect of Indian law and now will deal in brief with the experiences shared by South Africa, Brazil and Russia.

\section{BRICS Countries and Leniency: Glimpses from South Africa, Brazil \& Russia}

BRICS has been recognized as a strong grouping of the same category of economies termed 'emerging market economies' showcasing a remarkable increase in trade and business. Thereby the scope or rather the chances of market players indulging in anticompetitive activities like cartelization has increased. This makes it imperative for us to look at the approaches taken by the competition enforcement agencies of BRICS in busting cartels through the use of leniency programmes.

\subsection{South Africa}

The Competition Act of 1998 provides for "the establishment of a Competition Commission responsible for the investigation, control and evaluation of restrictive practices, abuse of dominant position, and mergers ... and, for prohibited practices, the imposition of administrative fines of up to " $10 \%$ of the firm's annual turnover in the Republic and its exports from the Republic during the firm's preceding financial year". Cartel prosecution was not the highest priority in the early years of the modern institution established in 1999. Resources were focused on merger review, increasing public awareness of the new competition rules, and testing and establishing practices and procedures. In 2003, the Competition Commissioner announced that more attention and resources would be devoted to cartels. Significant penalties were agreed in settlements in a few cartel cases, notably R20 million (International Health Distributors) and R223,000 (Pretoria Association of Attorneys) during the course of 2003-2004. These high profile cartel settlements signalled that henceforth cartels 
would attract serious penalties. In 2004, the Competition Commission South Africa instituted a leniency programme (revised in 2008) offering cartelists an alternative. The first application under the programme was received in the same year. ${ }^{16}$

The 2009 Competition Amendment Act, upon entering into force, criminalized cartel conduct and imposed individual liability. At the time, questions were raised as to whether this change would increase effectiveness in achieving the objectives assigned the Commission. The leniency policy allows for full leniency (immunity) only for the first qualifying applicant; subsequent applicants may receive a penalty reduction via a settlement agreement. The leniency policy was revised to, among other things, increase the predictability as to what would qualify applicants for leniency. Other changes allowed for oral or 'paperless' applications and introduced a marker system. Fifty-four leniency applications were received by September 2009; more than two-thirds of these in the twelve months ending 30 June 2009. Many were connected with the construction, energy and transport sectors.

\subsection{Brazil}

Cartels in Brazil are subject to both administrative law and criminal law. Administrative fines for cartels are 1 per cent to 30 per cent of total annual turnover, and fines on individuals are 10 per cent to 50 per cent of the fine imposed on the respective company. Other penalties can include exclusion from public procurement or access to official bank credit for five years. Criminal penalties include criminal fines and prison terms of two to five years.

Leniency for cartels was introduced in 2000 by way of a change in the law. The first leniency agreement was executed in 2003. By 2009, about 15 leniency agreements had been signed and at least 29 executives had been found guilty of cartel involvement by the criminal courts. The number of search warrants served to obtain evidence about cartels, an indicator of anti-cartel activity, accelerated: from 30 in 2003-2006 to 84 in 2007 and 93 in 2008.

The leniency programme allows applicants to receive a one-third to two-thirds reduction in financial penalties, depending on the effectiveness of the cooperation and good faith of the applicant. If the authority was unaware of the cartel when the application was received, full immunity may be granted, and it is possible for individuals to be granted immunity from administrative fines and criminal prosecution. The applicant must be the first to approach the authorities, not have been the leader, must confess, cease the cartel activity and effectively cooperate with the investigation. The applicant must apply to the Secretariat of Economic Law of the Ministry of Justice (SDE) and provide sufficient information to ensure conviction. To benefit from the company's leniency application, individuals must

16 UNCTAD Note on The use of leniency programmes as a tool for the enforcement of competition law against hardcore cartels in developing countries, TD/RBP/CONF.7/4, published on 26 August 2010, available at <http://unctad.org/en/Docs/tdrbpconf7d4_en.pdf> (accessed June 10, 2016). 
sign the agreement to cooperate in the same manner as the company. Individuals may apply separately if the company does not apply. A marker system reserves a place in the queue for up to thirty days. The programme includes a 'Leniency Plus' provision.

\subsection{Russia}

Cartels are subject to administrative law penalties in Russia; criminal law provisions are inactive. In 2007, a leniency programme was introduced via legal amendment and eight companies self-reported under the programme. The Federal Antimonopoly Service of the Russian Federation (FAS), i.e. the competition authority, increased its level of activity in 2008 as compared to 2007, initiating 355 investigations of restrictive agreements or concerted practices (a broader category than 'cartels') in 2008 , an increase of 54 per cent over 2007. Cartel fines totalled RUB1.5 billion in 2008, more than 359 times as much as in the previous year. However, the programme allowed simultaneous leniency applications. Consequently, for example, thirty-seven insurance companies applied simultaneously for leniency in the Rosbank case. Their applications were accepted and no fines were imposed. An amendment in 2009 to the Code on Administrative Violations limited the penalty reduction to the first applicant and disallowed simultaneous applications.

\section{Competition Policy: Options for Enforcement Agencies in Context of Leniency Policy}

While leniency programmes are undoubtedly one of the most effective cartel detection tools, their effectiveness increases when they are coupled with robust investigation and strict penalties. To benefit from existing leniency programmes, a jurisdiction must pro-actively fight against cartels. If this is not done, then all the efforts invested in developing clear and expanded leniency rules will be wasted.

With respect to leniency programmes the trend is towards restricting information originating, ultimately, from leniency applicants. Thus one country cannot rely on another country to generate information for follow-on domestic proceedings. In summary, fighting cartels may not be left to others.

The experience of BRICS countries shows that once the precondition of seriously fighting cartels is met, both domestic and international cartels can be detected by the countries using leniency programmes.

Some characteristics of developing countries may diminish the effectiveness of cartel leniency programmes. Close relationships among business people, a larger informal economy and a weaker 'competition culture' each sap the strength of a leniency programme's incentives. With respect to international cartelists, they prioritize applying for leniency in those jurisdictions where they are exposed to larger potential penalties, which may not include many developing countries. Developing 
countries may have higher opportunity costs in building institutional capabilities. Further, their legal systems may offer settlement processes that provide an adequate substitute. In these circumstances, in some jurisdictions the costs of a cartel-specific leniency programme may outweigh the benefits. ${ }^{17}$

\section{Concluding Remarks}

The objective of antitrust laws is not only to prevent practices that have an adverse effect on competition, but also to promote and sustain competition in markets, to protect the interests of consumers and to ensure freedom of trade. This is truly reflective of the changing economic conditions. Therefore, proper care and protection should be taken to ensure that the measures taken against anticompetitive practices do not go to the extent of interfering with the liberty of the traders and business people. A cooperative spirit should be adopted to safeguard the interests of the producers, the traders and the consumers. That way would truly promote the larger public interest. The law should bring within its purview all consumers who purchase goods or services regardless of the purpose for which the purchase is made. The competition law should be designed and implemented in terms of a dynamic competition policy of the state.

Indeed of all states. And here it seems appropriate that our final remarks relate to the first state to which our attention turned, India. Unfortunately, the anti-cartel enforcement activity of the Competition Commission of India has been wanting, largely as the result of the collection of inadequate evidence. In order to ensure an effective anti-cartel regime, it is essential to have a strong and robust leniency programme. The CCl's existing programme is unpredictable and does not incentivise whistle-blowers. In past cases, even the identity of the whistle-blower has not been protected. In contrast, in the European Union for example, over the last three years all cartel decisions have emanated from leniency applications. The advantage of an effective leniency regime is that it provides smoking-gun evidence, ensuring a finding of breach of law. Therefore, the $\mathrm{CCl}$ must redesign its leniency programme and follow international best practices. ${ }^{18}$

17 UNCTAD Note on The use of leniency programmes as a tool for the enforcement of competition law against hardcore cartels in developing countries, TD/RBP/CONF.7/4, published on 26 August 2010, available at <http://unctad.org/en/Docs/tdrbpconf7d4_en.pdf> (accessed June 10, 2016).

18 Naval Satarawala Chopra, Need for a strong, effective leniency programme, Business Standard: Need for Robust Competition Law, available at < http://www.business-standard.com/article/opinion/fora-robust-competition-law-116022100753_1.html> (last visited on 15 June 2016). 


\section{References}

Naval Satarawala Chopra, Need for a strong, effective leniency programme, Business Standard: Need for Robust Competition Law, available at <http://www.businessstandard.com/article/opinion/for-a-robust-competition-law-116022100753_1. html>

International Competition Network, Anti-Cartel Enforcement Manual, Chapter 2: Drafting and implementing an effective leniency policy, April 2014, available at $<$ http://www.internationalcompetitionnetwork.org/uploads/library/doc1005.pdf > (last visited on 15 June 2016).

International Competition Network, Defining Hard Core Cartel Conduct: Effective Institutions, Effective Penalties: Report by the ICN Working Group on Cartels; available at <http://www.internationalcompetitionnetwork.org/uploads/library/ doc346.pdf $>$.

Werden G.J., Hammond S.D., Barnett B.A., Deterrence and Detection of cartels: Using all the tools and sanctions, 56(2) The Antitrust Bulletin (2011).

Wouter P. J. Wils, Leniency in Antitrust Enforcement: Theory and Practice in The More Economic Approach to European Competition Law, 24 Conferences on New Political Economy 203-248 (D. Schmidtchen, M. Albert and S. Voigt, eds, Mohr Siebeck 2007).

\section{Information about the author}

Deepankar Sharma (Jodhpur, India) - Faculty of Law, Ph.D. Scholar \& Coordinator, Center for Competition Law \& Policy (CCLP) at National Law University Jodhpur (NH-65, Nagour Road, 342304, Mandore, Jodhpur, Rajasthan [India]); e-mail: deepankar707@ gmail.com). 